Western Washington University Western CEDAR

Woodring Scholarship on Diversity, Equity, \& Inclusion

2016

\title{
Just Scholarship! Publishing Academic Research with a Social Justice Focus
}

Maria del Carmen Salazar

Francisco Rios

Western Washington Unviersity, francisco.rios@wwu.edu

Follow this and additional works at: https://cedar.wwu.edu/woodring_dei

Part of the Education Commons

\section{Recommended Citation}

Maria del Carmen Salazar \& Francisco Rios (2016) Just Scholarship! Publishing Academic Research with a Social Justice Focus, Multicultural Perspectives, 18:1, 3-11, DOI: 10.1080/15210960.2016.1127073

This Article is brought to you for free and open access by the Woodring College of Education at Western CEDAR. It has been accepted for inclusion in Woodring Scholarship on Diversity, Equity, \& Inclusion by an authorized administrator of Western CEDAR. For more information, please contact westerncedar@wwu.edu. 


\section{Just Scholarship! Publishing Academic Research with a Social Justice Focus}

\author{
Maria del Carmen Salazar \\ University of Denver \\ Francisco Rios \\ Western Washington University
}

This article provides support to academics who are committed to engaging in scholarly activities in ways that promote an explicit social justice focus. Moreover, this article provides a broad overview of how to pursue social justice purposes in the field of education throughout the process of scholarly production and dissemination.

\begin{abstract}
I am an advocate when I write poems speaking on behalf of those without an opportunity to be heard, for one of the curses of segregation and subordination by class is the imposition of silence. The poems seek to release a voice caught in the collective throat. (Espada, 1998, p. 8)
\end{abstract}

There is no greater way to colonize a people then to render them silent. To gag a cultural community by ramming oppressive ideologies down their "collective throat" is akin to cultural genocide. The stories of those who have been marginalized must be unbounded, accurately portrayed, and recorded, thus capturing their power, resiliency, and possibilities. Scholars of color
(SOCs) are uniquely positioned to elicit the narratives of marginalized communities because of their shared social and cultural lived experiences. Moreover, SOC survive hegemonic forces that could render them mute; in response, they often strive to represent the stories of the "other" using the written word.

We, the authors, are SOCs. Throughout this article, we use the first person point of view to interrupt the hegemonic discourse in the academy that falsely depicts third person discourse as "neutral." We do not pretend to be neutral. We value publishing for social justice and in this article provide support for SOC in pursing justiceoriented scholarship. Also, we share our own experiences in writing for a social justice purpose, including both challenges and opportunities.

As SOCs, we are keenly aware of the unique needs that faculty of color face as they begin and move through their career trajectory within the professorate. Numerous scholars have documented the differential expectations, standards, and impact of university promotion and tenure evaluation systems when applied to SOC (Baez, 2000; Gardner \& Blackstone, 2013; Thompson, 2008). For example, SOC face greater service demands in comparison to their White colleagues because of their distinct visibility in predominantly White institutions, unique perspectives related to diversity, and unwavering 
commitment to mentoring students of color (Baez, 2000; Thompson, 2008). SOC often engage in service as a means of furthering their commitment to social justice and challenging institutional barriers for the advancement of communities of color (Baez, 2000). Institutions of higher education (IHE) that commit to student diversity call upon SOCs frequently to help promote these institutional goals. Unfortunately, high levels of service often correlate with fewer scholarly publications, thus exacerbating the obstacles for promotion and tenure (Gardner \& Blackstone, 2013).

\section{The stories of those who have been marginalized must be unbounded, accurately portrayed, and recorded, thus capturing their power, resiliency, and possibilities.}

SOCs are often viewed as experts around diversity related issues due to their ethnic backgrounds, irrespective of their disciplinary expertise (Laden \& Hagedorn, 2000). But we also know that their ethnic expertise can work against them. SOC express that their scholarship is devalued, disparaged, and dismissed via claims that they have too "narrow" a focus on issues of race and social justice (Baez, 2000; Thompson, 2008). Moreover, SOC report facing bias from White students who perceive them as less competent in comparison to White faculty, often resulting in negative teaching evaluations (Thompson, 2008). As a result, SOC face differential treatment, significant challenges in meeting promotion and tenure requirements, and limited opportunities for advancement (Baez, 2000; Laden \& Hagedorn, 2000).

In addition to these professional hardships, SOC also confront additional struggles when considering the "scholarship" requirements of their work. Some of the major challenges identified by SOC (Delgado Bernal \& Villalpando, 2002; Rockquemore \& Laszloffy, 2008; Thompson, 2008; Turner, 2003) include the following:

- Lack of confidence in their abilities;

- Challenges about social positioning and telling one's story;

- Perceptions of bias and lack of rigor;

- A sense of isolation and marginalization; and,

- Lower rankings of journals that publish work valued by SOC.

We are also keenly aware that an additional challenge presents itself to SOC who employ a social justice-orientation to their work and call for social change. These important works are often perceived as being steeped in liberal values, lacking objectivity, and advancing a specific "agenda." Moreover, the scholarship of SOC is criticized for being biased, thus affirming the masternarrative that scholarship should be neutral. The result is that SOC, especially those who are probationary, are socialized early in their careers to use mainstream approaches to scholarship. In doing so, they give up a central part of who they are (identity) and why they pursued the professorate in the first place (purpose). This is equated to being silenced (Solorzano \& Yosso, 2002), becoming mute (Hendrix, 2010), and ultimately losing one's soul in the academy (Rockquemore \& Laszloffy, 2008). In many ways, this is akin to what Joel Springs (1994) described as deculturalization, or stripping away and replacing the cultures of conquered communities. This phenomenon may also be considered a systemic approach to descholarization (Brickman, 1975) in the professorate in that the unique contributions of SOC become marginalized and lost as they are lured into the "whitestream" (Grande, 2000).

As the only tenure-track Latina professor at my IHE for 10 years, I, Maria, experienced a deep sense of isolation. I lacked a community of SOC with whom I could commiserate, collaborate, and produce scholarship. I lacked mentoring on publishing, much less publishing for social justice purposes. This was exacerbated by the fact that I did not feel confident as a writer. I had never seen models of Latina writers in my $\mathrm{K}-12$ or undergraduate schooling experiences. My first experience with the scholarship of Latinas was in my doctoral program. I was inspired by the work of Gloria Anzaldua, Sonia Nieto, Dolores Delgado Bernal, and Maria Franquiz. I had never experienced the written word in such a way; their scholarship touched the innermost caverns of my soul. It was in that moment that I knew that I had been starving intellectually, and I wanted to experience the nourishing power of the written word. But beyond this, I wanted to use this power to relate my experiences within hegemonic educational structures, challenge oppression, and advocate for marginalized cultural communities. The intensity and authenticity of Latina scholars helped me to believe in my own potential as a writer, or counter-storyteller, and so I embarked on this journey to use my voice as a tool to challenge oppression and advocate for social justice.

At one point, I, Francisco, rejected the idea of pursuing my doctoral degree. I viewed professors of colleges of education at universities as disconnected from the everyday realities of not only teachers and teaching but also the cultural community where I was a member. How could anyone aspire to that, I thought? My many mentors, however, inspired me forward, reminding me that our communities have important stories to tell-and that I had a responsibility, given the many opportunities 
afforded me, to tell those stories. These mentors also shared that our community needed role models to show ourselves and others who people like us could be. "You have no choice," one of my mentors told me when discussing my pursuit of the professorate as part of our community uplift. It was their consejos, confianza, and coraje that propelled me forward, providing that much needed sense of purpose for what I, as an SOC, needed to do. For me, academic scholarship has been about telling stories of students and teachers of color in terms of both oppression and resistance.

SOCs have had numerous occasions to participate in professional development focused on "writing for publication," both as participants and as presenters. Many of these writing for publication workshops focus generically on the process of moving from research to the actual production and dissemination via professional journals. For young SOC new to the profession, these workshops often serve as a professional lifeline essential for their success as academics in predominantly white institutions. We write this article to share our perspectives on how scholars who write with a social justice focus might do so purposefully and effectively. We assert that this will help SOC to maintain their integrity while still being successful with writing for publication within the bounds of acceptable scholarly standards. In short, this article provides an overview of how SOCs can pursue social justice purposes in the field of education throughout the process of scholarly production and dissemination.

The focus of this work is on writing articles for academic journals. We do so while being keenly aware that there are other important outlets for publications, such as books and book chapters, as well as a visual mediums (i.e., documentaries) and new mediums (i.e., blogs, wikis, webpages, etc.) for publicizing academic research. Likewise, we are writing this to academics who are employed in college and university settings. But we recognize and honor the importance of those scholars who work within community organizations and use their academic talent to directly advance the community where they are situated.

\section{Defining Social Justice}

Given the nearly amorphous use of the term, we begin by providing a broad definition of social justice so that readers might understand how we employ the term. A comprehensive definition of this term is beyond the scope of this article given that we recognize the multiple (and sometimes contested) definitions of the term. We encourage readers to pursue other definitions that are consonant with their understanding of social justice.

For us, social justice is a term that spans multiple disciplinary fields, from sociology and psychology, to critical legal studies and urban education. Within the field of education, it is most apparent in critical multicultural education, critical race theory, and anti-racist education (see, for example, Kumashiro, 2015; LadsonBillings \& Tate, 1995; May \& Sleeter, 2010; Solorzano $\&$ Bernal, 2001). Social justice in education was spurred by the long, though historically relatively obscure work in ethnic studies as well as women/gender studies, which became prevalent and robust as a result of the Civil Rights Movement (Rios \& Munoz, 2012).

Social justice provides a critical lens for questions on diversity, equity, inclusion/access, power, privilege, inequality, and the stratification of individuals based on social identity. Rather than centering the individual as the unit of analysis, SOCs focus on the structural (especially institutional policies and practices), discursive (national narratives), and ideological (underlying assumptions and beliefs about phenomena, including the epistemological). Elevating the unit of analysis beyond what occurs at the individual level is one of the most important elements of employing a social justice framework (Scheurich \& Young, 1997). With respect to diversity, it includes a variety of social identities (race, class, language, gender, legal status, sexual orientation, exceptionality, etc.) as well as their intersections. Social justice is critical, if not outright hostile, toward deficit ideologies applied to individuals and their communities (Valencia, 2010). Instead it identifies and embraces the social-cultural capital and assets of marginalized communities (Yosso, 2006).

Social justice in education focuses on inequities in curriculum, instruction, assessment, policies, procedures, and preparation (Bull, 2008). For example, social justice topics in education include, but are not limited to standards-based instruction (Sleeter \& Cornbleth, 2011), school discipline (Payne \& Welch, 2015), school reform (Kumashiro, 2015), school finance (Rodriguez \& Rolle, 2013), language policies (Nieto, 2013), civic education (Youniss, 2011), curriculum (Salinas, 2006; Zamudio, Russell, Rios, \& Bridgeman, 2011), assessment (Lee, 2013), tracking (Cammarota, 2014), segregation (Anyon, 2014), and teacher and principal preparation (Franquiz, Salazar, \& DeNicolo, 2011).

We now turn our attention to the production of articles for publication. We do so by focusing on preconditional considerations in writing for publication. Next, we focus on the production of articles. We end with considerations for submitting articles.

\section{Determining a Social Justice Purpose}

While the actual writing of articles is where the proverbial rubber meets the road, we acknowledge a key consideration in positioning yourself to write for 
publication is to understand your own motivation to publish. A legitimate answer to the question is for professional advancement. Additionally, there is great pride in seeing your work published in a journal that is read by your peers and used to extend academic conversations in the discipline. Many scholars, having developed a productive research protocol that garnered important findings, hope that sharing their results might interrupt inequity and advance educational quality. Completing a research project and sharing it with others is part and parcel of what it means to engage in academic scholarship.

It is also important to ask why SOCs strive to write for social justice. Collins (2013) encouraged us to write to speak truth to power as well to generate dialogue within our respective social-cultural communities. SOCs often write to challenge taken for granted conventions and thereby shift the conversation that is occurring within the academic discipline. Questioning the academic field is a process that begins while considering the problem to be studied, continues throughout the research design process, and comes to fruition when sharing the study with external publics.

SOCs attempt to challenge the field by working to address significant social challenges with special attention to understanding and working toward disrupting injustice. From our experiences, the primary end goal of many SOC who are social justice educators is to confront and attempt to resolve social problems. Publishing is the vehicle used to accomplish this goal. They do this by documenting hegemonic realities, such as the inequalities that result when tracking students into different academic ability groups. For example, Cammarota (2014) engaged high school students in participatory action research to analyze the disparities that resulted from academic tracking in their school.

Moreover, SOC social justice educators also address social challenges by documenting unintended impacts of policies and practices that are intended to alleviate educational inequalities but instead, exacerbate the inequalities. As a case in point, Nieto (2014) argued that the No Child Left Behind Act (NCLB) was framed as an attempt to hold schools accountable to and for the outcomes of all students. Yet, she revealed that unintended negative impacts have resulted from the near manic use of standardized assessments with the concomitant narrowing of the curriculum (teaching only those subjects that were being tested) and instructional strategies (teaching for test performance). Documenting impact might also include whether or not enacted policies and/ or practices maintain power relations, reduce student/ family agency, and maintain or disrupt the actual material conditions of people's lives.

SOCs hope that our scholarship has the strength to change repressive discourses in the academic field; periodically something substantial comes along that has this impact. However, we believe it is more important to recognize that it is the culmination of small challenges, questions, and deliberations that lead to the big changes in the field. We think it is empowering and motivating to see yourself as a collaborator among peers who are working to make change in the academic field and advance social justice. This makes the work you are engaged in "bigger than yourself." If nothing else, an important goal of writing for broad social justice purposes is to develop in yourself and your readers a critical consciousness that may lead to praxis. All of this is predicated on a recognition that scholars can and do make a difference for positive social change.

Lastly, it is important to note that the relationship between identity and writing with a social justice focus. As you pursue social justice focused scholarship, recognize that you are also establishing a personal and professional identity. In doing so, you are able and willing to situate your place in research and in the broader professorial community. It has the concomitant impact of helping to connect you with other like-minded scholars and practitioners.

\section{Framing Scholarship with a Social Justice Focus}

Once you have established the broad purpose(s) for choosing to engage in scholarship for social justice aims, you need to be explicit about how you are framing the academic initiative in which you are engaged. Important in this regard is to read social justice-oriented scholarship. This recognizes and honors the fact that your scholarship is predicated upon the publications of those social justice advocates whose work has come before your own; their efforts make your scholarship possible. But more than that, this is the literature review that frames the story that is the backdrop for your scholarship. Social justice-oriented scholarship that you read will also be instrumental in helping you to understand the scope of the problem more fully and how others have approached this problem theoretically, empirically, personally, and communally. It connects you with like-minded scholars and adds to the conversation in the field. In saying this, we urge you to remain open to a broad range of social justice-oriented scholarship you might read, including historical accounts, narratives, and both fiction and nonfiction.

Closely related to the literature you review is the importance of employing a liberatory theoretical framework. All quality scholarship is anchored in a framework that helps you conceptualize the problem, the methodology, the analysis of data, etc. Thus, the theoretical framework you take is central to your academic stance and identity as a social justice scholar. Fortunately, there 
are many strong liberatory theoretical frameworks. Consider just these few as exemplars of some of the strongest social justice scholars: critical pedagogy (Darder, Friere, McLaren), critical race theory and its ethnic specific offshoots (Brayboy, Ladson-Billings, Solorzano), de-colonizing (Smith), anti-hegemonic (Apple, Gramsci), anti-oppressive (Kumashiro), Queer (Loutzenheiser), Disability (Connor \& Gabel), Black Feminist (Hill-Collins, hooks), critical multicultural (May \& Sleeter), etc. These frameworks will push you in several ways: to understand you own positionality and epistemological lenses; to examine the overt but also the covert; to ask about who is included and who is excluded; to view phenomena from an institutional, ideological, ecological, discursive, and social ethos level of analysis, raising above the level of analysis that focuses on the individual; and, to envisage conceptual and practical approaches to disrupting inequality.

While it would be best to take a strong liberatory approach, if you must write within more traditional theoretical frameworks within the field, at minimum assure you are not employing a hegemonic theoretical framework. Hegemonic frameworks "privilege certain groups and identities in society while marginalizing others, and they legitimatize this order by couching it in the language of 'normalcy' and "commonsense"" (Kumashiro, 2000, p. 36). Such frameworks reproduce inequities, normalize oppression, and denigrate historically disenfranchised communities (Kumashiro, 2001; Pillow, 2003;

Rodriguez, 2013).

Another consideration has to do with the methodologies employed. In this realm, we are especially informed by some very promising practices emerging in contemporary scholarship. For example, SOCs work with community based organizations, community leaders, and/or community organizations (NAACP, for example) in poor and ethnic minority communities to understand what they need to know, get their recommendations about possible methodologies to employ, access their resources to gather data, engage them in the analysis of the data, and disseminate the findings (with them as copresenters) to the broader community, first and foremost, about the results of the study and related recommendations. As two examples, consider the work done by a group of scholars who met with Latino community representatives throughout the United States to establish a national Latino research agenda - the National Latino/a Research and Education Project (Pedraza \& Rivera, 2006). A second example is the participatory action research projects that Duncan-Andrade and Morrell (2008), and others (Cammarota, 2014; Fine, 2012) engage in to inspire mostly urban, poor, and ethnic minority youth to use scholarly inquiry to document their living and learning conditions.

\section{Writing with a Social Justice Perspective}

Assuming you have done the initial preparation in that you are clear about your purpose, read works by social justice scholars who employ liberatory theoretical frameworks, and use a methodology that speaks to the needs of those in the community you wish to serve, the next step is to write. With this prior work in hand, there are important decisions to make about the story you tell and how you want to tell it. Given that this is the most creative aspect of the entire writing for publication experience, you need to be purposeful and deliberate about the words and discourses you use to tell a story. It is vital to write with a powerful voice. For us, writing with a powerful voice asks you to assert whatever principles of social justice, equity, excellence, inclusion, diversity, power, privilege, etc., that most directly speak to your experience and research project you have completed. It is, in short, asking you to draw from your own story and research to take a strong stance for social justice.

Even in the most data rich publication where the data tell much of the story, there are spaces in the introduction (framing), analysis, discussion, and conclusion, even within the most traditional academic discourse formats, to advocate on behalf of the marginalized and to oppose "isms" and other forms of injustice. Consider the section of the article you write that includes implications for practice as the beginning of a larger theory to practice piece directed at practitioners in the field. Also consider a section that includes a discussion on public policy implications of the project. Your voice can be amplified and have impact as a scholarly publication, a position article, or an editorial that may possibly influence public policy in your university, community, state, the nation, or the global community.

When writing the article, we especially encourage you to tap into the power of narratives and stories of real people in real-life situations. In some cases, it may be your own counter-narrative that you share to challenge master-narratives, or interrupt "neutral" forms of expression that are privileged in scholarly writing. There is a special power in telling stories that disrupt tacit, taken for granted, assumptions about communities of color, and the stereotypes often held about them. This humanizes the experience of those that are often dehumanized and silenced. Espada (1998) wrote, "Eduardo Galeano has written, 'I write for those who cannot read me.' These are the human beings who, in the words of Wolfgang Binder, 'run the risk of leaving this earth unrecorded."'(p. 8). The use of narratives in research is powerful in that it captures the complexity of human lives (Josselson, 2006). This complexity includes what Chapman (2005) described as the "nature of 'voice,' what it represents, who it represents, and who has the power to assert it" (p. 27). SOCs often grapple with the 
nature of voice and how to represent the experience of those who are othered (Chapman, 2005; Kushamiro, 2000). But in our experiences, writing our own stories is cathartic, empowering, and soul-saving.

We recognize that much of the academic research and publication process seems as if it all falls on the individual. We strongly encourage you to make writing a social process. One of the first things to do is to consider whether you want this to be an individual project or a collaborative project with others. This meets the ways of knowing for those SOC who value a more communal approach to the production of knowledge. Moreover, there are important advantages of working collaboratively. Among other things, there is the proverbial "two heads are better than one" in terms of the overall strength of the scholarly project. Often working with a colleague, or colleagues, is motivating because you have others who you need to be accountable to in terms of moving projects forward. And working with others also shares the load of the labor of engaging in this work. But there are also some drawbacks as well: you can often become stuck if one of your collaborators isn't doing their part of the work. We often underestimate the time it takes to negotiate shared meaning around the work that is being produced. And some institutions, especially those that are researchintensive, require academics to produce single-author publications as part of the tenure process.

Even if you are writing individually, you can still make writing social by connecting with like-minded scholars and contacting established scholars who might serve, informally or formally, as mentors for the project. Seek out other social justice-oriented scholars to help you refine your work by providing counsel for framing, analyzing, writing, and submitting the work. It is helpful if you can identify a small group of colleagues who can serve as potential informal external reviewers of your work before submitting it formally for publication. Find someone who is especially good at writing mechanics and writing clarity. Ask someone who brings a strong social justice stance to read for the degree to which it reflects that purpose, and reach out to a critical friend, someone who will ask the tough questions and get you to think about your work in a more nuanced (and hence more complete) way. Above all, have at least two people read your work if at all possible before submitting it formally for review.

\section{Disseminating Social Justice Scholarship}

The next consideration is which journals you choose to submit your work. A key principle is that you need to consider the audience you want to read your work when choosing publication outlets. This goes back to why you chose to do a social justice project in the first place since this will also direct you to for whom it should be disseminated. You also need to balance those journals that might have the greatest prestige and professional audience with your sense about which journal would be most open to your work. For example, consider impact factor, readership, and fit. To get this sense more directly, you can send an extended abstract to the editors of journals you have identified and see if they feel your work is a "fit" for their journal. You also have to consider those audiences you most wish to reach may favor a practitioner-oriented article and thereby need to expand your sphere of influence by writing such.

We would be remiss if it seemed as if we were offering these recommendations without considering the contextual constraints that you must operate under. You write at your own peril if you do not attend to the institutional expectations that are required for tenure and/or promotion in terms of journal selection, authorshipsole or joint - and author order, types of scholarly work, etc. In many IHEs, some journals carry more weight for tenure and promotion review than do other journals. We strongly urge you to understand fully the institutional requirements for tenure and promotion and to pursue these relentlessly. We also suggest you to encourage social justice advocates in your department, who are tenured, to work within the institutional settings to broaden the definition of whose knowledge counts and the value of communicating that knowledge beyond traditional academic circles.

While there are many strong journals to consider, some of our favorites for promoting social justice in education related research include the following: Equity and Excellence in Education; Rethinking Schools; Race, Ethnicity, and Education; Diaspora; Minority and Indigenous Education; Latinos in Education; Multicultural Perspectives; Bilingual Research Journal; Urban Education; Race, Class and Gender; and the International Journal of Multicultural Education. One productive approach to locating other such journals is to review the journals listed in the reference section of your own publication. Also, it is important to read recent articles in the journal to identify ways to structure and organize your publication so your social justice message is clear and targeted.

It bears repeating that it is important to consider how to get the most from your publication in terms of scholarly and community impact. For example, inform your local, national, and international colleagues about your work. Encourage them to read and cite your work. List your publications and post your updated curriculum vitae on your university portfolio site. Join scholarly networks that disseminate information about your scholarship such as the ResearchGate. Concomitantly, get the word out about your scholarly work to the communities most impacted by the issue you address, but especially to 
the community where you completed the work. This means you may need to produce "collateral products" such as editorials, press releases, works for practice-oriented journals, etc. that are read by the people in the community. Another way to frame this is to consider how you have to become academically "multilingual" by way of communicating rich and significant academic ideas and concepts through linguistic scaffolds for multiple audiences.

\section{Additional Considerations When Writing for Publication}

We wish to share some thoughts about feedback received from editors. Expect to receive feedback and requests for revisions for most articles that are submitted for peer review. Rarely, you may receive an "accepted" without changes. Periodically you will receive notice that your article is accepted pending minor changes; we urge you to make those minor changes and resubmit the work with all deliberate speed. More often, you will receive a revise and resubmit; note that this is not a "reject" and that the editor believes that the article demonstrates promise. In this instance, you have to decide whether the work to make the revisions is worth the effort. We also urge you to not make any changes that violate the integrity of the scholarly work. If that is the case (or in the case of a reject), take the feedback that is provided that you find useful and identify a different journal that might be more receptive to your social justice focus. Sharing the work with a senior scholar whose opinion you value to ascertain the article's overall merits can also be helpful.

Along with all these considerations, we also acknowledge that there is often less support for social justice oriented research. While there is plenty of funding, contemporarily, for Science, Math, Technology, and Engineering (STEM), there is often limited funding available to study diversity and equity issues. This should not be interpreted to mean there is no fiscal support but rather that there is less and it is harder to garner. Of course, there are certainly possibilities for engaging an interdisciplinary STEM project where access and equity are a central part of the study. For example, a recent Google search for terms that joined science with social justice resulted in 40 million sites; a Google search connecting math and social justice netted 7 million sites. The interest in social justice STEM research merits closer examination and often has strong potential for funding.

We also would be remiss if we did not acknowledge that writing with a social justice focus is more challenging in certain academic disciplines. For example, we realize that writing an article on quantum mechanics from a social justice perspective is uncommon. However, we believe that all disciplines can be conceptualized through the lens of just scholarship.

While this article has focused on SOCs, we do not aim to leave out our White allies. White scholars, alongside SOCs, have bolstered notions of social justice in education to new heights in the past 3 decades including Sleeter, McLaren, Apple, Faltis, Ayers, Zeichner, and Cochran-Smith, to name but a few. These scholars have been stalwart advocates of marginalized communities, thus interrupting oppression by telling the stories of those who are "othered" (Kumashiro, 2001). As SOC, we welcome the efforts of our White allies, particularly as reviewers on journals with a social justice focus, prereviewers of articles, advocates on SOC tenure files, and supporters of SOC junior colleagues.

\section{... we must not lose sight of our purpose for entering the academy: to uphold what is good and just in the academy and simultaneously dismantle that which is repressive to our communities. We seek to tear down the gates to the Tower and make it ivory no longer, but rather a blending of colors that represent our global society.}

However, it is important to note that when expressing the voices of those who have been, and continue to be marginalized, White scholars must avoid the white saviour [sic] complex. Straubhaar (2014) described the white savior complex as a sense that "Westerners have the unique power to uplift, edify, and strengthen" (p. 384). Straubhaar added that at times White scholars do not acknowledge the benefits accorded to them because of their history as colonizers and the existing social structures that privilege Whiteness. Thus, we caution White scholars to acknowledge their privilege and respect the dignity of those who have been historically marginalized. Communities of color do not need to be fixed, changed, or saved. We have the power to improve our own communities, in collaboration with our White allies.

White scholars must also guard against the "pobrecito syndrome" or the "poor little ones" mentality (FloresOrtiz, 2003). This belief system reifies deficit notions of marginalized communities and is focused on how our communities are incapable, inferior, and require lowered 
expectations (Huerta \& Brittain, 2009; Soledad, 2013).

Scholarship that perpetuates stereotypes, isms, and oppression has no room in the academe of today.

\section{Conclusion}

The topic on SOCs publishing academic research for a social justice purpose is important for academy. We face many challenges and opportunities in publishing for social justice. Many topics for future research emerge from this topic, including exploring criticisms that the work of SOCs is limited in scope, as compared to White scholars who are lauded as social justice crusaders when they do research on marginalized communities, identifying alternative mediums for publishing and disseminating scholarly work that increases our relevance and impact in marginalized communities, advising graduate students on exploring social justice issues in their dissertations and scholarly publications, and identifying methods for moving our ideals from theory to practice to real and sustained transformation.

As the number of SOC faculty entering the "ivory tower" increases, the definition of scholarship will morph and transform into a kaleidoscope that captures the interests and needs of the many cultural communities we represent. As change advances, we must not lose sight of our purpose for entering the academy: to uphold what is good and just in the academy and simultaneously dismantle that which is repressive to our communities. We seek to tear down the gates to the Tower and make it ivory no longer, but rather a blending of colors that represent our global society. SOCs are disrupting the present and envisioning the future, and along with our White allies, we will transform the academy with the power of our collective voices and just scholarship.

We end with Espada's call for us to be responsible and relentless in telling the compelling stories, via academic scholarship, of those from our cultural communities who are marginalized but who create spaces for living with dignity. At times, these stories are our own. Espada (1998, p. 8) wrote:

If I know Mrs. Báez, a Dominican immigrant living in the burned-out wreckage of a building torched by her landlord, then I am obligated to record her painfully dignified ritual of serving coffee to strangers. If I know Jacobo Mena, a Guatemalan artist, a refugee from political persecution on the verge of being deported, who cleaned offices by night and painted stunning landscapes by day, I am compelled to write of his colors, his green and red. To know what a cockroach may become embedded in a child's ear is to accept responsibility for that knowledge, to communicate that knowledge for the sake of those who do not know, and those who do. How could I know what I know, and not tell what I know? (emphasis added)

\section{References}

Anyon, J. (2014). Radical possibilities: Public policy, urban education, and a new social movement. New York, NY: Routledge.

Baez, B. (2000). Race-related service and faculty of color: Conceptualizing critical agency in academe. Journal of Higher Education, 39, 363-391.

Brickman, W. W. (1975). The descholarization of the university: A modest proposal. Intellect, 104(2369), 187.

Bull, B. L. (2008). Social justice in education. New York, NY: Palgrave MacMillan.

Cammarota, J. (2014). The social justice education project. In J. Cammarota \& A. Romero (Eds.), Raza Studies: The public option for educational revolution (pp. 107-121). Phoenix, AZ: University of Arizona Press.

Chapman, T. K. (2005). Expressions of "voice" in portraiture. Qualitative Inquiry, 11(1), 27-51.

Collins, P. H. (2013). Truth telling and intellectual activism. Contexts, 12(1), 36-41.

Delgado Bernal, D. \& Villalpando, O. (2002). An apartheid of knowledge in academia: The struggle over the "legitimate" knowledge of faculty of color. Equity and Excellence in Education, 35(2), $169-180$.

Duncan-Andrade, J., \& Morrell, E. (2008). The art of critical pedagogy: Possibilities for moving from theory to practice in urban schools. New York, NY: Peter Lang Publishing, Inc.

Espada, M. (1998). Zapata's disciple: Essays. Cambridge, MA: South End Press.

Fine, M. (2012). Youth participatory action research. In N. Lesko \& S. Talburt (Eds.), Keywords in youth studies: Tracing affects, movements, knowledges (pp. 318-324). New York, NY: Routledge Press.

Flores-Ortiz, Y. (2003). Re/membering the body: Latina testimonies of social and family violence. In A. J. Aldama (Ed.), Violence and the body: Race, gender, and the state (pp. 347-359). Bloomington, IN: Indiana University Press.

Fránquiz, M. E., Salazar, M., \& DeNicolo, C. P. (2011). Challenging majoritarian tales: Portraits of bilingual teachers deconstructing deficit views of bilingual learners. Bilingual Research Journal, 34 (3), 279-300.

Gardner, S. K., \& Blackstone, A. (2013). "Putting in your time": Faculty experiences in the process of promotion to professor. Innovative Higher Education, 38(5), 411-425.

Grande, S. (2000). American Indian identity and intellectualism: The quest for a new red pedagogy. International Journal of Qualitative Studies in Education, 13(4), 343-359.

Hendrix, K. G. (2010). "Did being Black introduce bias into your study?": Attempting to mute the race-related research of Black scholars. Howard Journal of Communication, 13(2), 153-171.

Huerta, T. M., \& Brittain, C. M. (2009). 26 effective practices that matter for Latino children. In E. G. Murillo, S. Villenas, R. T. Galvan, J. Sanchez Munoz, C. Martinez, \& M. Machado-Casas (Eds.), Handbook of Latinos and education: Theory, research, and practice (pp. 382-399). New York, NY: Routledge.

Josselson, R. (2006). Narrative research and the challenge of accumulating knowledge. Narrative Inquiry, 16(1), 3-10.

Kumashiro, K. K. (2000). Toward a theory of anti-oppressive education. Review of Educational Research, 70(1), 25-53.

Kumashiro, K. K. (2001). "Posts" perspectives on anti-oppressive education in social studies, English, mathematics, and science classrooms. Educational Researcher, 30(3), 3-12. 
Kumashiro, K. K. (2015). Against common sense: Teaching and learning toward social justice. New York, NY: Routledge.

Laden, B. V., \& Hagedorn, L. S. (2000). Job satisfaction among faculty of color in academe: Individual survivors or institutional transformers? New Directions for Institutional Research, 2000(105), $57-66$.

Ladson-Billings, G., \& Tate IV, W. (1995). Toward a critical race theory of education. The Teachers College Record, 97(1), 47-68.

Lee, D. K. (2013). Teacher education for democracy and social justice. New York, NY: Routledge.

May, S., \& Sleeter, C. E. (Eds.). (2010). Critical multiculturalism: Theory and praxis. New York, NY: Routledge.

Nieto, S. (2013). Finding joy in teaching students of diverse backgrounds: Culturally responsive and socially just practices in US classrooms. Portsmouth, NH: Heinemann.

Nieto, S. (Ed.). (2014). Why we teach now. New York, NY: Teachers College Press.

Payne, A. A., \& Welch, K. (2015). Restorative justice in schools: The influence of race on restorative discipline. Youth and Society, 47 (4), 539-564.

Pedraza, P., \& Rivera, M. (Eds.). (2006). Latino education: An agenda for community action research. New York, NY: Routledge.

Pillow, W. (2003). Race-based methodologies: Multicultural methods or epistemological shifts? Counterpoints, 181-202.

Rios, F., \& Munoz, E. (2012). Mexican-American (Chicano) education. In J. A. Bands (Ed.), Encyclopedia of diversity in education (pp. 1472-1476). Thousand Oakes, CA: Sage Publishers.

Rockquemore, K. A., \& Laszloffy, T. (2008). The Black academic's guide to winning tenure-without losing your soul. Boulder, $\mathrm{CO}$ : Lynne Rienner Publishers.

Rodriguez, G. M. (2013). Power and agency in education: Exploring the pedagogical dimensions of funds of knowledge. Review of Research in Education, 37(1), 87-120.

Rodriguez, G. M., \& Rolle, R. A. (2013). To what ends and by what means: The social justice implications of contemporary school finance theory and policy. New York, NY: Routledge.

Salinas, C. (2006). Educating late arrival high school immigrant students: A call for a more democratic curriculum. Multicultural Perspectives, 8(1), 20-27.
Scheurich, J. J., \& Young, M. D. (1997). Coloring epistemologies: Are our research epistemologies racially biased? Educational Researcher, 26(4), 4-16.

Sleeter, C. E., \& Cornbleth, C. (2011). Teaching with vision: Culturally responsive teaching in standards-based classrooms. New York, NY: Teachers College Press.

Soledad, A. M. (2013). Does the reconstruction process improve a school? Journal of Border Educational Research, 2(1), 4-7.

Solorzano, D. G., \& Bernal, D. D. (2001). Examining transformational resistance through a critical race and LatCrit theory framework Chicana and Chicano students in an urban context. Urban Education, 36(3), 308-342.

Solorzano, D. G., \& Yosso, T. J. (2002). Critical race methodology: Counter-storytelling as an analytical framework for education research. Qualitative Inquiry, 8(1), 23-44.

Spring, J. (1994). Deculturalization and the struggle for equality: A brief history of the education of dominated cultures in the U.S. New York, NY: McGraw-Hill Inc.

Straubhaar, R. (2014). The stark reality of the 'White Saviour'complex and the need for critical consciousness: A document analysis of the early journals of a Freirean educator. Compare: A Journal of Comparative and International Education, 45(3), 381-400.

Thompson, C. (2008). Recruitment, retention, and mentoring faculty of color: The chronicle continues. New Directions for Higher Education, 143, 47-54.

Turner, C. (2003). Incorporation and marginalization in the academy: From border toward center for faculty of color? Journal of Black Studies, 34(1), 112-125.

Valencia, R. R. (2010). Dismantling contemporary deficit thinking: Educational thought and practice. New York, NY: Routledge.

Yosso, T. J. (2006). Critical race counterstories along the Chicanal Chicano educational pipeline. New York, NY: Routledge.

Youniss, J. (2011). Civic education: What schools can do to encourage civic identity and action. Applied Developmental Science, 15(2), 98-103.

Zamudio, M., Russell, C., Rios, F., \& Bridgeman, J. L. (2011). Critical race theory matters: Education and ideology. New York, NY: Routledge. 